\title{
Purification of Nucleic Acids by Hybridization to Affinity Tagged PNA Probes
}

\author{
Henrik Ørum \\ PNA Diagnostics A/S, Rønnegade 2, 6.floor, 2100 Copenhagen $\varnothing$, Denmark
}

\begin{abstract}
The use of affinity tagged PNA capture probes offers an efficient means for the purification of nucleic acids by hybridization. Two different approaches are described. A sequence specific method and a generic method. The sequence specific method requires sequence information on the target and synthesis of a dedicated PNA. It can be used to selectively purify the nucleic acid containing the target from non-related nucleic acids and other cellular components. The generic method uses a "universal" triplex forming PNA and requires no sequence information on the target. It can be used in the bulk purification of large nucleic acids.
\end{abstract}

\section{Introduction}

Biological material has been shown to contain many substances that can inhibit invitro enzymatic manipulation of nucleic acids (1-4). Methods that facilitate efficient purification of nucleic acids from complex starting material are therefore of considerable interest.

To provide maximum separation power the purification method should exploit a unique property of the nucleic acids. An obvious choice is the ability of single stranded nucleic acids to form Watson-Crick hydrogen bonded duplexes with complementary synthetic DNA probes. Using this property, homothymine DNA probes carrying affinity tags or coupled directly to solid supports have been used successfully to purify bulk mRNA by hybridization to the poly(A) tail $(5,6)$. Although the "purification by hybridization" approach ought to be applicable to the purification of other classes of nucleic acids and specific target molecules, it does not appear from the literature to be widely used.

Part of the reason for this is that the use of DNA capture probes faces a number of practical problems. One of these are the need for high affinity capture probes that provide a probe/target stability that will survive the purification procedure (710). In practise this means that rather large DNA probes are required, the consequences of which are 1) a reduced ability of the probe to discriminate between closely related target sequences and 2) an increase in the complexity of preparing the probes. Another often encountered problem with DNA capture probes is poor accessibility of the target sequence which can be caused by undesired inter- or intra-molecular hybridization event involving the target. Capture of dsDNA, for instance, can be hampered by competition from the complement strand. Likewise, stable intramolecular structures, which occurs in several classes of nucleic acids like rRNAs, tRNAs and snRNAs - and which may also occur by chance in individual mRNAs - may limit target sequence accessibility. 
PNA is ideally suited to tackle these problem. Firstly, the high $\mathrm{T}_{\mathrm{m}}$ of even moderately sized PNA probes (11) usually ensures adequate probe/target stability's whilst maintaining good specificity. The increased affinity further provides PNA with a competitive advantage over the corresponding nucleic acids in binding to its target sequence. When the PNA is able to form a triplex (i.e., consisting of pyrimidine residues exclusively) and thus able to bind to dsDNA by "strand invasion" $(12,13)$ this competitive advantage is at its maximum.

Secondly, when PNA is used as capture probes, the hybridization conditions can be adjusted so as to unwind nucleic acid structures (thereby making them accessible for hybridization) whilst not affecting PNA binding $(11,14)$. This possibility is a consequence of the uncharged nature of the PNA oligomer, which allows hybridization in the absence of the counterions needed to stabilise nucleic acid duplexes. Taking advantage of these properties, we have developed two different PNA based methods for purifying nucleic acids by hybridization; a sequence specific method (14) and a generic method (15).

The sequence specific method uses duplex forming PNAs carrying $\mathrm{His}_{6}$ affinity tags in combination with Ni-NTA affinity columns to purify the target nucleic acid. The method requires sequence information on the target nucleic acid and synthesis of a dedicated PNA. Using an oligonucleotide model system the method was shown to allow selective enrichment of a fully complementary target over a single base mismatched target oligo. Also, the use of a low ionic strength buffer was shown to facilitate efficient capture of a hairpin oligonucleotide which could not be captured under conditions normally used for nucleic acid hybridization. When in vitro transcribed RNAs, varying in sizes from 257 to 2224nt., were used as targets, an inverse relationship between the size of the target and the efficiency of capture was observed. Efficient capture of the large target, however, could be significantly improved by the simultaneous use of several different PNAs.

The generic method exploits the unique ability of short homopyrimidine PNAs to form extremely stable triplexes with homopurine DNA targets $(12,13)$. The triplex between a PNA $\mathrm{T}_{7}$ and a DNA A ${ }_{7}$, for instance, exhibit a thermostability of $63.3^{\circ} \mathrm{C}$. Since a $7 \mathrm{nt}$. sequence will on average occur by chance every $16.4 \mathrm{~kb}$ in nucleic acids (assuming a 50\% GC content), small triplex forming PNAs ought to function as generic probes for the capture of large nucleic acids. This contention was verified using biotinylated bisPNA-T $7(16,17)$ in combination with streptavidin-coated magnetic particles to efficiently purify human genomic DNA from whole blood. When lysed blood was added to the PCR reaction without prior purification as little as $5 \mu l$ totally inhibited the amplification process. After PNA- $\mathrm{T}_{7}$ purification, however, amplification could easily be conducted with an amount corresponding to $500 \mu \mathrm{l}$ of blood. In a prospective study of 12 individuals (6 males and 6 females) the method, in all cases, was found to provide DNA that could be PCR amplified using sets of primers directed against target genes located on chromosomes 1 and 7 and the $\mathrm{X}$ chromosome.

\section{Protocols}

\section{Sequence Specific Method}

1. The hybridization reaction (typically $200 \mu \mathrm{l}$ ) contains $2 \mathrm{M}$ Urea, $20 \mathrm{mM} \mathrm{Na}_{2} \mathrm{HPO}_{4}$ $(\mathrm{pH} 8.0), 0.5 \mathrm{M} \mathrm{NaCl}, 0.1 \%$ Triton X-100, $1 \mu \mathrm{M}$ of $\mathrm{His}_{6}$-PNA capture probe and lysed sample.

2. Heat to $95^{\circ} \mathrm{C}$ for $5 \mathrm{~min}$. and hybridise for $10 \mathrm{~min}$ at the desired temperature. With the PNAs analysed so far, good specificity and fast hybridization kinetics have been observed at temperatures between 20 to $25^{\circ} \mathrm{C}$ below the measured $\mathrm{T}_{\mathrm{m}}$.

3. Load the hybridization reaction onto a Ni-NTA spin column (prepared in advance as described below) and centrifuge at $200 x \mathrm{~g}$ for $30 \mathrm{sec}$ (no incubation time on the Ni-NTA column is necessary). 
4. Wash the column several times to remove non-specifically bound material by adding $200 \mu \mathrm{l}$ of hybridization buffer (2M Urea, $20 \mathrm{mM} \mathrm{Na}_{2} \mathrm{HPO}_{4}(\mathrm{pH} 8.0), 0.5 \mathrm{M} \mathrm{NaCl}$, $0.1 \%$ Triton $\mathrm{X}-100$ ) followed by centrifugation at $200 x \mathrm{~g}$ for $30 \mathrm{sec}$.

5. Elute the purified target nucleic acids by (i) adding $200 \mu \mathrm{l}$ of hybridization buffer to the column and (ii) incubating the column at $95^{\circ} \mathrm{C}$ for $5 \mathrm{~min}$ and (iii) centrifuging at $200 x \mathrm{~g}$ for $30 \mathrm{sec}$.

The elution procedure is designed to maintain the $\mathrm{His}_{6}$-PNAs on the column and only release the capture target nucleic acids. If desired, however, exchanging the hybridization buffer with $100 \mathrm{mM}$ of EDTA can elute the entire His 6 -PNA/DNA complex.

\section{Preparation of Spin Column}

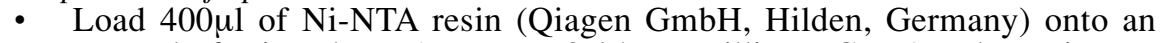
Eppendorf spin column (Durapore $0.45 \mu \mathrm{m}$; Millipore Corp.) and centrifuge at 200x $g$ for $30 \mathrm{sec}$ to remove the Ni-NTA storage buffer.

- Wash the column several times by adding $200 \mu \mathrm{l}$ of water followed by centrifugation at $200 x \mathrm{~g}$ for $30 \mathrm{sec}$.

- Add 200ul of hybridization buffer (2M Urea, 20mM Na $2 \mathrm{HPO}_{4}(\mathrm{pH} 8.0), 0.5 \mathrm{M}$ $\mathrm{NaCl}, 0.1 \%$ Triton X-100) to the column. Remove the hybridization buffer by centrifugation at $200 x \mathrm{~g}$ for $30 \mathrm{sec}$ immediately before use.

\section{Generic Method}

The generic method has been optimised for the (i) purification of human genomic DNA from whole blood and to allow (ii) direct PCR on the captured nucleic acids whilst bound to the streptavidin coated magnetic particles. Using a different lysis buffer and lysis procedure the method was found to facilitate efficient purification of the cryptic plasmid of Chlamydia trachomatis from urine samples (18).

1. The lysis reaction contain up to $100 \mu$ l of whole blood and $100 \mu$ l of lysis buffer (100mM Tris. $\mathrm{HCl}$ ( $\mathrm{pH} 8.5$ ), 50mM KCl, 6mM MgCl $2,0.02 \%$ Triton X-100 and $1 \mathrm{mg} / \mathrm{ml}$ Proteinase K (Boehringer Mannheim; added immediately before use), 100pmol of biotinylated bisPNA $\mathrm{T}_{7}$, and water to a final volume of $200 \mu \mathrm{l}$ in an Eppendorf tube.

2. Incubate the reaction at $55^{\circ} \mathrm{C}$ for $15 \mathrm{~min}$, , then at $100^{\circ} \mathrm{C}$ for $10 \mathrm{~min}$ to simultaneously denature the genomic DNA and inactivate the proteinase $\mathrm{K}$ (active proteinase $\mathrm{K}$ may digest the streptavidin on the magnetic particles added in step 6).

3. Centrifuge the sample at $12000 x \mathrm{~g}$ to pellet cellular debris (when less than $25 \mu \mathrm{l}$ of blood is used this step can be omitted).

4. Transfer the supernatant to a new Eppendorf tube and incubate for $10 \mathrm{~min}$. at room temperature to allow the PNA to hybridise.

5. Wash $20 \mu \mathrm{g}$ of streptavidin-coated magnetic beads (Dynabeads ${ }^{\mathrm{R}} \mathrm{M}-280$; Dynal $\mathrm{A} / \mathrm{S}$, Oslo, Norway) in $200 \mu \mathrm{l}$ of wash buffer (20mM Tris- $\mathrm{HCl},(\mathrm{pH} 8.3), 100 \mathrm{mM}$ $\mathrm{KCl}, 3 \mathrm{mM} \mathrm{MgCl}, 0.1 \%$ zwittergent) and resuspend in $50 \mu \mathrm{l}$ wash buffer.

6. Add the $50 \mu \mathrm{l}$ of beads to the hybridization reaction and shake at room temperature for $10 \mathrm{~min}$ at $1200 \mathrm{rpm}$ to allow the Bio-PNA/DNA complex to bind to the beads.

7. Collect the beads with a magnetic beads concentrator (Dynal A/S) and wash twice with $200 \mu$ l of wash buffer.

8. Resuspend the beads in $20 \mu$ l of water and transfer directly to the PCR reaction.

\section{Examples}

One of the potentially most useful features of PNA in sample preparation is its ability to hybridise to the target nucleic acid in the absence of counterions. Thus, by simply lowering the salt concentration in the hybridization buffer one can 
selectively unwind nucleic acid structures that may otherwise limit the access of the PNA to its target sequence.

To demonstrate the practicability of the "low salt" approach we attempted to capture a "hairpin" oligonucleotide in which the entire $15 \mathrm{nt}$. PNA target sequence was part of the stem structure (Figure 1). The oligonucleotide was radioactively labelled with ${ }^{32} \mathrm{P}$ and incubated for $10 \mathrm{~min}$ at room temperature in the presence of a complementary $\mathrm{His}_{6}$-PNA in either high salt $\left(20 \mathrm{mM} \mathrm{Na}_{2} \mathrm{HPO}_{4}(\mathrm{pH} 8.0), 500 \mathrm{mM}\right.$ $\mathrm{NaCl}, 0.1 \%$ Triton $\mathrm{X}-100$ and $2 \mathrm{M}$ urea) or low salt $\left(1 \mathrm{mM} \mathrm{Na} 2 \mathrm{HPO}_{4}(\mathrm{pH} 8.0)\right.$, $0.1 \%$ Triton $\mathrm{X}-100$ and $2 \mathrm{M}$ urea). After hybridization the sample was loaded onto a Ni-NTA column and taken through the procedure outlined above. Finally, the radioactivity in the run-through, washes and eluents were counted in a scintillation counter. As shown in Figure 2 essentially all the radioactive material is found in the run-through and first wash when hybridization is conducted in the high salt buffer were the hairpin structure should be stable. In contrast, more than $50 \%$ of the radioactivity is recovered in the eluent when hybridization is conducted in the low salt buffer where the hairpin structure should be significantly destabilised.

\section{Application and Limitations}

Purification by hybridization is an appealing approach whereby nucleic acids can be efficiently separated from non-nucleic acid components in a biological sample. With PNA there are two options; sequence specific or generic purification. Which method will be most suitable depends on the objective. If small nucleic acids are to be purified then the generic approach might fail because of lack of the target sequence. In this case, and in cases where the objective is to purify a specific target nucleic acid from a background of unrelated nucleic acids, the sequence specific method must be used. The efficiency of this method, however, decreases with increasing size of the target molecule. Hence, when large nucleic acids are to be purified, or the objective is to obtain bulk nucleic acids then the generic method is most suitable.

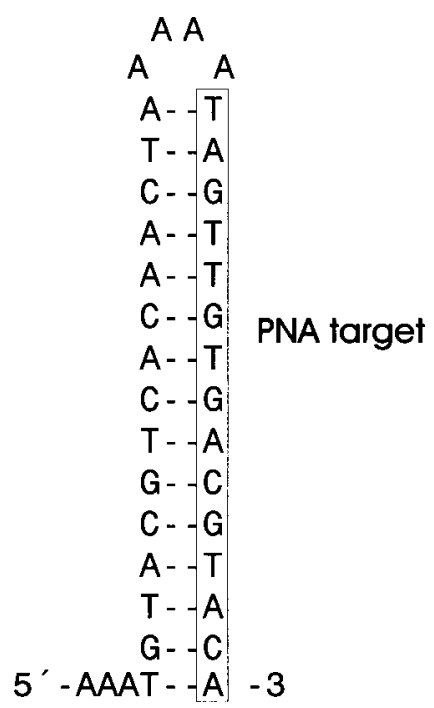

Figure 1. Sequence and predicted secondary structure of the 37 mer synthetic target oligonucleotide. 


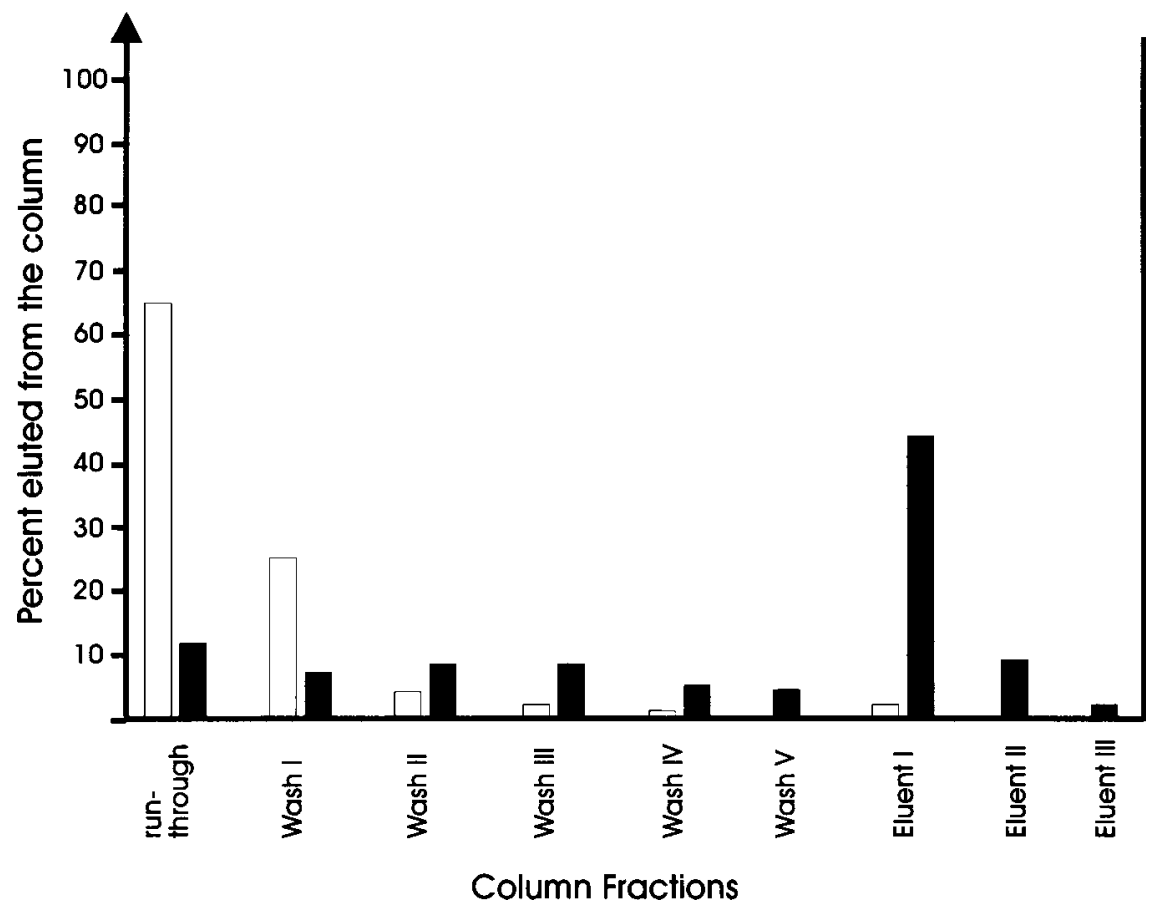

Figure 2. Capture efficiency of the hairpin oligonucleotide depicted in Figure 1 as a function of the ionic strength of the hybridization buffer. The radioactivity in each of the fractions is represented as the percentage of total radioactivity in all fractions. White bars: High salt, Black bars: Low salt.

\section{References}

1. Greenfield, L. and T.J. Write. 1993. Sample preparation methods. In:Diagnostic Molecular Biology: Principles and Applications. D.H. Persing, T.F. Smidt, F.C. Tenover and T.J. Write (eds.), American Society for Microbiology, Washington, D.C. p. 122-137.

2. Mercier, B., C. Gaucher, O. Feugeas and C. Mazurier. 1990. Direct PCR from whole blood, without DNA extration. Nucl. Acids Res. 18: 5908.

3. Panaccio, M. and A. Lew. 1991. PCR based diagnosis in the presence of $8 \%$ (vol/vol) blood. Nucl. Acids Res. 19: 1151.

4. Rossen, L., P. Norskov, K. Holmstrom and O.F. Rasmussen. 1992. Inhibition of PCR by components of food samples, microbial diagnostic assays and DNA extraction solutions. Int. J. Food Microbiol. 17: 37-45.

5. Hornes, E. and L. Korsnes. 1990. Magnetic DNA hybridization properties of oligonucleotide probes attached to superparamagnetic beads and their use in the isolation of poly(A) mRNA from eucaryotic cells. Genet. Anal. Tech. Appl. 7: $145-150$.

6. Kuribayashi, K., M. Hikata, O. Hiraoka, C. Miyamoto and Y. Furuichi. 1988. A rapid and efficient purification of poly(A)-mRNA by oligo(dT) ${ }_{30}$-Latex. Nucl. Acids Res. Symposium series. 19: 61-64.

7. Fry, G., E. Lachenmeier, E. Mayrand, B. Giusti, J. Fisher, L. Johnston-Dow, 
R. Cathcart and Finne, E. 1992. A new approach to sequencing template purification with paramagnetic particles. Biotechniques. 13: 124-131.

8. Jagus, R. 1987. Hybrid selection of mRNA and hybrid arrest of translation. Meth. Enz. 152: 567-572.

9. Ricciardi, R.P., J.S. Miller and B.E. Roberts. 1979. Purification and mapping of specific mRNAs by hybridization-selection and cell-free translation. Proc. Natl. Acad. Sci. USA. 76: 4927-4931.

10. Soh, J. and S. Pestka. 1992. Hybrid selection of mRNA with biotinylated DNA. Meth. Enz. 216: 186-196.

11. Egholm, M., O. Buchardt, L. Christensen, C. Behrens, S.M. Freir, D.A. Driver, R.H. Berg, S.K. Kim, B. Norden and P.E. Nielsen. 1993. PNA hybridizes to complementary oligonucleotides obeying the Watson-Crick hydrogen-bonding rules. Nature. 365: 566-568.

12. Nielsen, P.E., M. Egholm, R.H. Berg and O. Buchardt. 1991. Sequence selective recognition of DNA by strand displacement with a thymine-substituted polyamide. Science. 254: 1497-1500

13. Egholm, M., P.E. Nielsen, O. Buchardt and R.H. Berg. 1992. Recognition of guanine and adenine in DNA by cytosine and thymine containing peptide nucleic acids (PNA). J. Am. Chem. Soc. 114: 9677-9678.

14. Ørum, H., P.E. Nielsen, M. Jørgensen, C. Larsson, C. Stanley and T. Koch. 1995. Sequence specific purification of nucleic acids by PNA-controlled hybrid selection. Biotechniques. 19: 472-479

15. Seeger, C., Batz, H-G. and Ørum. H. (1997). PNA-mediated purification of PCR amplifiable human genomic DNA from whole blood. Biotechniques. 23: 512-517.

16. Egholm, M., L. Christensen, K.L. Dueholm, O. Buchardt, J. Coull and P.E. Nielsen. 1995. Efficient $\mathrm{pH}$-independent sequence-specific DNA binding by pseudoisocytosine-containing bis-PNA. Nucl. Acids Res. 23: 217-222.

17. Griffith, M.C., L.M. Risen, M.J. Greig, E.A. Lesnik, K.G. Sprankle, R.H. Griffey, J.S. Kiely and S.M. Freier. 1995. Single and bis peptide nucleic acids as triplexing agents: Binding and stoichiometry. J. Am. Chem. Soc. 117: 831832.

18. Borre, M.B., M. Næsby and H. Ørum. 1997. PNA used for specific capture of nucleic acids. In: Gene Cloning and Analysis: Current Innovations. B. Schaefer ed., Horizon Scientific Press, Wymondham, UK. pp. 61-72. 


\section{Further Reading}

Caister Academic Press is a leading academic publisher of advanced texts in microbiology, molecular biology and medical research. Full details of all our publications at caister.com

- MALDI-TOF Mass Spectrometry in Microbiology Edited by: M Kostrzewa, S Schubert (2016) www.caister.com/malditof

- Aspergillus and Penicillium in the Post-genomic Era Edited by: RP Vries, IB Gelber, MR Andersen (2016) www.caister.com/aspergillus2

- The Bacteriocins: Current Knowledge and Future Prospects Edited by: RL Dorit, SM Roy, MA Riley (2016)

www.caister.com/bacteriocins

- Omics in Plant Disease Resistance Edited by: V Bhadauria (2016) www.caister.com/opd

- Acidophiles: Life in Extremely Acidic Environments Edited by: R Quatrini, DB Johnson (2016) www.caister.com/acidophiles

- Climate Change and Microbial Ecology: Current Research and Future Trend

Edited by: J Marxsen (2016)

www.caister.com/climate

- Biofilms in Bioremediation: Current Research and Emerging Technologies

Edited by: G Lear (2016)

www.caister.com/biorem

- Microalgae: Current Research and Applications Edited by: MN Tsaloglou (2016) www.caister.com/microalgae

- Gas Plasma Sterilization in Microbiology: Theory, Applications, Pitfalls and New Perspectives Edited by: H Shintani, A Sakudo (2016) www.caister.com/gasplasma

- Virus Evolution: Current Research and Future Directions Edited by: SC Weaver, M Denison, M Roossinck, et al. (2016) www.caister.com/virusevol

- Arboviruses: Molecular Biology, Evolution and Control Edited by: N Vasilakis, DJ Gubler (2016) www.caister.com/arbo

- Shigella: Molecular and Cellular Biology Edited by: WD Picking, WL Picking (2016) www.caister.com/shigella

-Aquatic Biofilms: Ecology, Water Quality and Wastewater Treatment

Edited by: AM Romaní, H Guasch, MD Balaguer (2016)

www.caister.com/aquaticbiofilms

- Alphaviruses: Current Biology

Edited by: S Mahalingam, L Herrero, B Herring (2016)

www.caister.com/alpha

- Thermophilic Microorganisms

Edited by: F Li (2015)

www.caister.com/thermophile
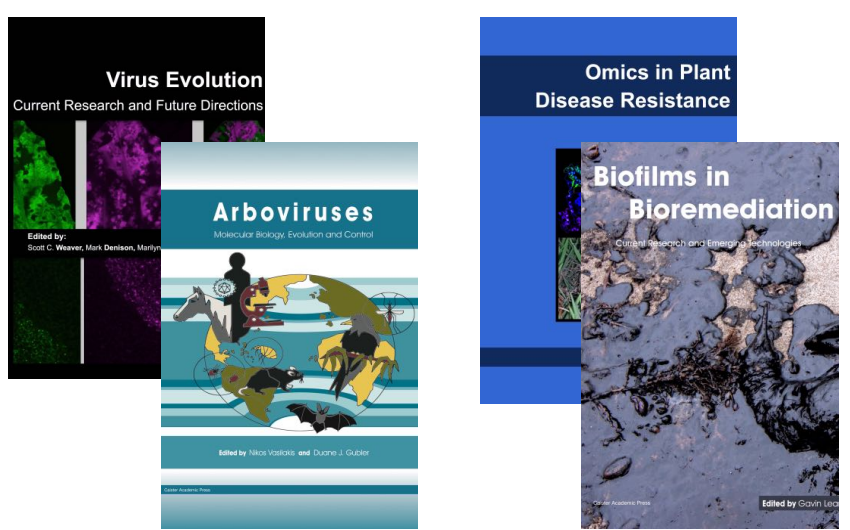
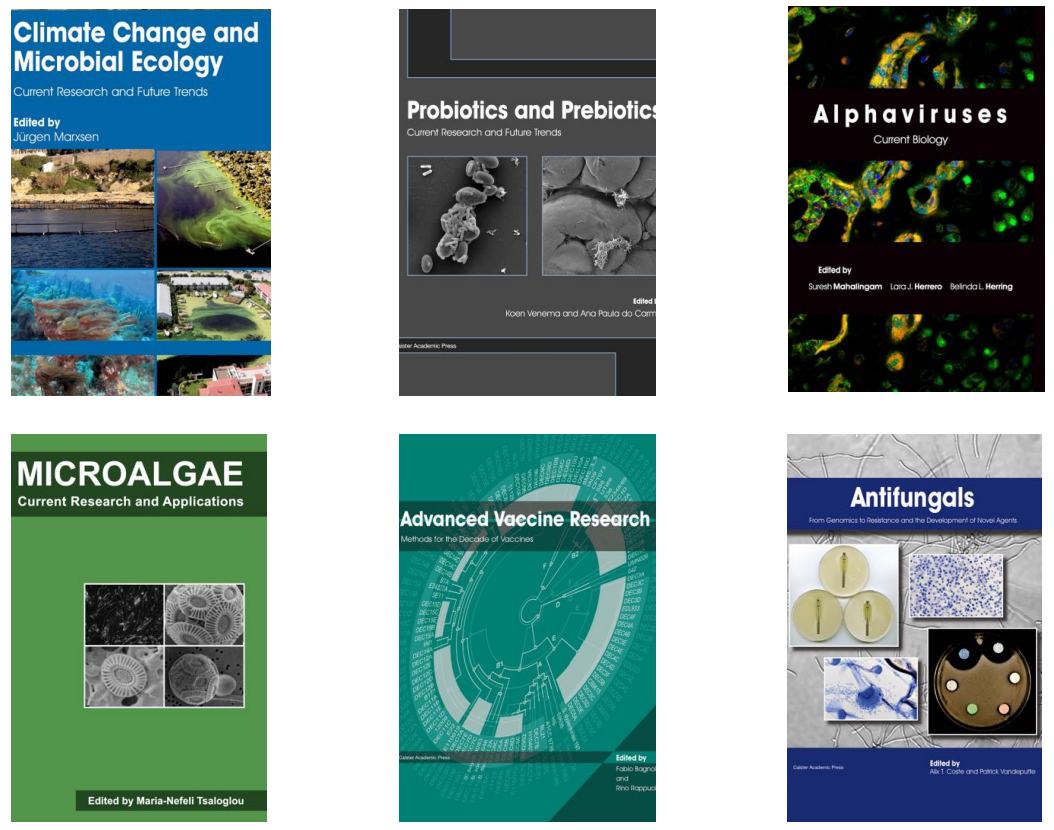

- Flow Cytometry in Microbiology: Technology and Applications Edited by: MG Wilkinson (2015) www.caister.com/flow

- Probiotics and Prebiotics: Current Research and Future Trends Edited by: K Venema, AP Carmo (2015) www.caister.com/probiotics

- Epigenetics: Current Research and Emerging Trends Edited by: BP Chadwick (2015) www.caister.com/epigenetics2015

- Corynebacterium glutamicum: From Systems Biology to Biotechnological Applications

Edited by: A Burkovski (2015)

www.caister.com/cory2

- Advanced Vaccine Research Methods for the Decade of Vaccines

Edited by: F Bagnoli, R Rappuoli (2015)

www.caister.com/vaccines

- Antifungals: From Genomics to Resistance and the Development of Novel Agents

Edited by: AT Coste, P Vandeputte (2015)

www.caister.com/antifungals

- Bacteria-Plant Interactions: Advanced Research and Future Trends Edited by: J Murillo, BA Vinatzer, RW Jackson, et al. (2015) www.caister.com/bacteria-plant

\section{- Aeromonas}

Edited by: J Graf (2015)

www.caister.com/aeromonas

- Antibiotics: Current Innovations and Future Trends

Edited by: S Sánchez, AL Demain (2015)

www.caister.com/antibiotics

- Leishmania: Current Biology and Contro Edited by: S Adak, R Datta (2015) www.caister.com/leish2

- Acanthamoeba: Biology and Pathogenesis (2nd edition) Author: NA Khan (2015)

www.caister.com/acanthamoeba2

- Microarrays: Current Technology, Innovations and Applications Edited by: Z He (2014)

www.caister.com/microarrays2

- Metagenomics of the Microbial Nitrogen Cycle: Theory, Methods and Applications

Edited by: D Marco (2014)

www.caister.com/n2 